160

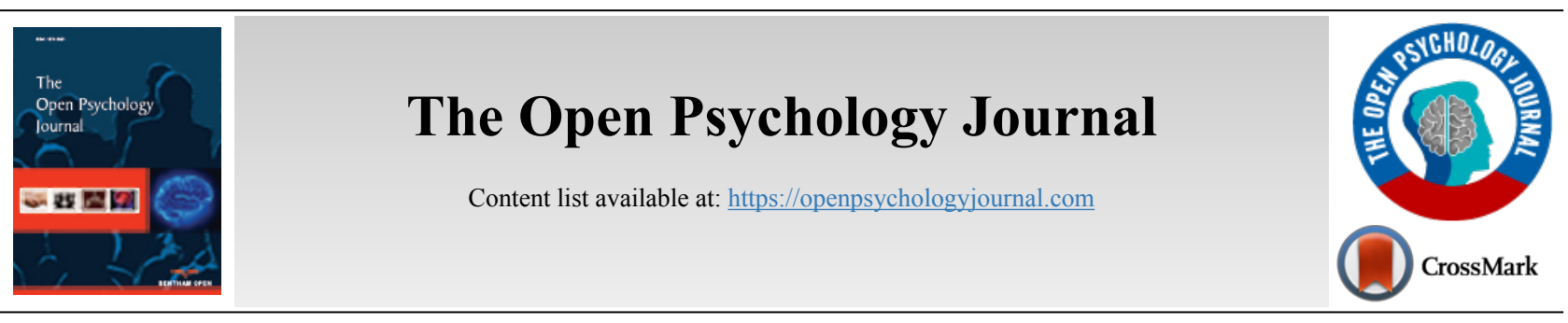

RESEARCH ARTICLE

\title{
Theoretical Foundations of Adolescent Development through Tagiuri's Taxo- nomy: Analysis of Educational Setting as an Organizational Climate
}

\author{
Mehmet Aslan ${ }^{1, *}$, Suzana Kosir ${ }^{1}$ and Marine Levidze ${ }^{1}$ \\ ${ }^{1}$ Department of General Education, Liberal Arts, American University of the Middle East, Dasman, Kuwait
}

\begin{abstract}
:
Background:

Research on student attachment and adolescent development indicates that negligence or lack of support during development processes such as social, emotional, and psychological processes could cause severe harm to their future lives in adulthood. Thus, delinquent behaviors may occur as less severe in peer pressure, academic challenges, family problems and as more severe in truancy, drop-out, academic failure, substance usage, juvenile crimes, suicidal tendencies, etc.
\end{abstract}

Aims:

In this regard, the present study aims at providing theoretical foundations of adolescent development through Tagiuri's four scaled taxonomy in order to analyze the school environment as an organizational climate: ecology, milieu, social system, and culture.

Methods:

Based on the presented literature review, content analysis was used to present different theoretical foundations of adolescents based on Taqiuri's four scaled taxonomy on school attachment. The content analysis helped us to analyze the presence, meaning and relationship of certain themes or concept.

Results:

The study shows that one of the significant challenges that appear for educational settings is to find ways and strategies to address students developmental and academic needs in a fashion of preventing delinquent behaviors and fostering adaptive behaviors. One of the major findings of the study suggests that educational performance and enhancement should be measured together with the four scaled taxonomy to reach a complete framework of a bonding model in education.

\section{Conclusion:}

The study also aims at providing an overview of the research on Attachment Theory and its relation with Tagiuri's four scaled taxonomy by analysis of a comprehensive research table in the field.

Keywords: Student development, Adolescence , School attachment, Adaptive and delinquent behavior, Tagiuri's taxonomy , Scaled taxonomy

\begin{tabular}{|l|l|l|l|}
\hline Article History & Received: January 30, 2020 & Revised: May 29, 2020 & Accepted: June 03, 2020 \\
\hline
\end{tabular}

\section{INTRODUCTION}

Adolescence, as a transitional and developmental period that occurs between childhood and adulthood, coexists together with diverse challenges of development resulting in either adaptive or delinquent behavior dependent on the type, degree, and circumferences of the challenge. Puberty, with its concrete,

* Address correspondence to this author at the Department of General Education, Liberal Arts, American University of the Middle East, P.O.Box: 220 Dasman, 15453, Dasman, Kuwait; Tel: +965 2225 1400; Ext: 2088;

E-mail: Mehmet.Aslan@aum.edu.kw visible and biological changes, is considered as the initiation of adolescence. Nevertheless, other changes occur through less concrete processes like social, emotional, and psychological modifications. Academic achievement or school performance is very much related to students' relations with school. If adolescents have good relations with their schools, they would stay longer for their extracurricular activities and attend classes with contentment. The focus of research and psychologists that are working together with schools and educational institutions has traditionally been on assessment, avoidance, and 
measurement with numerous key factors that have an impact on academic performance. On the other hand, performance enhancement variables require some solid information about developmental designs that can be perceived both with adaptive and delinquent aspects. In this regard, the current study suggests that to reach an efficient practice of school psychology, Tagiuri`s four scaled taxonomy can be used to assess adaptive and delinquent behaviours as enhancement variables of schools as organizational settings.

School Attachment (hereafter SA) as a recently developed concept is similarly used as School Connectedness, School Engagement, School Climate, School Involvement, Students` Satisfaction, School Bonding, etc [1]. In particular, attachment, bonding, and connectedness have been used to define students` attachment to schools by researchers [2]. Thus, attachment is one of the basic needs of students attending schools, which should be met by fully prepared schools in order to make deviant behaviour a reason for failing the school or classes. The fact that attachment should be seen as a student's basic need is one of the significant points of SA and school psychology studies that should be empirically tested. By such studies, it can be explained if students` individual negative senses of belonging to school are also the sources of their delinquencies and if these feelings have an impact on avoiding positive feelings for school or whether the low levels of SA are due to students' school life as a common environment. In this regard, the present study also aims to investigate the role of Tagiuri's four scaled taxonomy in the analysis of organizational climate by creating a comprehensive table together with attachment and organizational studies.

Since schools are organizations, SA has been widely studied under organizational attachment studies, which helped with comprehending the school environment and its particular characteristics. As a result, theories on organizations with a focus on the human aspect are crucial in the comprehension of SA.

Tagiuri, Litwin, and Barnes [3] studied the theories of environment and organizations, and proposed organizational environment with a three-level model and defined interior environment of the organization as: (a) experiences of members, (b) organization's influences on their behaviour, and (c) values of a specific set of traits [3]. Later on, he developed his three levelled model to a four-level model, same as a specific composition of individual traits build the personality, he presented his model as follows; 1) ecology, the physical side of the environment; 2) milieu, people within the environment; 3) social system - the interrelations between people within the environment; and 4) culture as the beliefs, norms, and values shared within the environment [3].

There have been several theoretical approaches to SA. Three developmental theories were suggested by Catalano, Haggerty, Oesterle, Fleming, and Hawkins [2], including Attachment Theory [4, 5], Social Control Theory [6], and the Social Development Model [7]. However, diversity in terminology and analysis of variables together with other structures has been an obstacle to studies due to inconsistency of which inconvenient analysis and results caused confusion on previous and present studies [8]. In this regard, the current study focused on the organizational model of Tagiuri's four scaled taxonomy as it seemed to be neglected by research. Thus, the main purpose of the present study was to analyze Tagiuri's four scaled taxonomy: Ecology, Milieu, Social System and Culture that provide a structural approach to school climate in the enhancement of SA among students by not only buffering the delinquent behaviors but also helping researchers define attachment as part of organizational climate for educational settings.

\section{LITERATURE REVIEW}

Research on attachment indicates that only $50 \%$ of students experience some kind of attachment to schools [9], considering attachment is opposite to isolation, the other $50 \%$ might be feeling alienated from communal activities or school life [10]. School attachment is also related to well-being, sociological, pedagogical, and psychological development of youth, as it is one of the essential elements that help students gain skills for facing challenges and achieving success [9, 11 - 13]. Studies conducted on youth resiliency described developmental elements like attachment as positive predictors on resiliency enhancement for the future of youth [9, 11 - 14]. School attachment was also considered as a negative predictor for misconduct and risk factors like truancy, dropout, failure, delinquency, etc $[1,11,14,15]$. as the attachment was mentioned to be a strong and significant motivational factor for both adolescents and adults, in particular impacting academic achievement outcomes.

Apart from the above-mentioned attachment studies that were focused on students feelings for school, there were many other studies conducted on the school environment other than Tagiuri's four levelled model in an attempt to systemize, conceptualize, classify and determine the variables that make environmental factors, as well as their impacts on SA. Murphy, Weil, Hallinger, and Mitman [16] proposed a structure for the academic climate that urges students for achievement with an emphasis on a standardized climate which would stimulate people within the organization to act with expected behaviours and explain academic pressure as the key for achievement that can be reached through both students and staff: "Degree to which school forces press for student achievement on a schoolwide basis" [16]. They also emphasized the significance of school regulations and class activities that foster academic press.

McDill, Rigsby, and Meyers Jr [17]. studied some high schools' instructional and social climates and reached six elements of the school environment: 1) student perception of intellectualism-aestheticism - the relations between school staff and students through SPS (students 'perceptions of school), particularly, the stressors for academic achievement; 2) academic emulation - a medium for academic success; 3) scientism with a focus on science; 4) cohesive and egalitarian aestheticism, highlighting intellect as the criteria for status and students` social unification within school's communal system; 5) academically oriented student status system, a medium of academic success between peer associations; and 6) humanistic excellence - a factor of drive in increasing students ' attraction and maintenance for social sciences. 
Moos [18] suggested another six-level theoretical standpoint to determine variables of the environment and to study their relations with behaviour in an analytical way: 1) behaviour settings; behavioural and environmental features with a purpose of defining student's experiences and behaviours; 2) organizational structure - systematic relations between an organization`s divisions and their standpoints; 3) ecological dimensions - factual ergonomics of an organization as in architecture, location, internal design, etc.; 4) psychosocial characteristics and organizational climate; development of the individual, relationships, maintenance of the infrastructural and divisional aspects of the organization; 5) functional or reinforcement properties of environments; mechanisms of control on motivational aspects of specific behaviours, and 6) personal and behavioural characteristics of the inhabitants; personal traits of people living in the organization. He asserted that "categories of dimensions are nonexclusive, overlapping, and mutually interrelated" [18]. Moos, Clayton, and Max [19] further suggested a four divisional system including 1) physical setting, 2) organizational factors 3) human aggregate, and 4) social climate. After a considerable revision, they suggested a furtherdeveloped nine social environment ratio [20].

To enhance and formulate a healthy school concept, Hoy and Fedman [21] suggested a seven-dimensional and three levelled structure in order to reach, maintain, and test the wellbeing of communal relationships in a school. They stressed the concept of health in the following way: "healthy school is one in which the teachers, administrators, and the board are in harmony, and the school meets both its organizational and people needs as it pursues its missions" [22]. The three levelled structure is: (1) school board level; institutional integrity was mentioned as a school's ability of preserving its scholar dignity from outer factors. (2) administrational level; initiating structure, was the leader's rules of behaviour aiming at success; consideration, targeting equilibrium of communal relations with expected leader behaviour; resource support, indicated administrative behaviour in provision of needed materials for school; and principal influence was redirecting the principle's skills to having influence over superiors. (3) teacher level; morale, stated the communal feelings between teachers, and academic emphasis, referred to the extension of pressure over students for achievement. Later, together with Kottkamp in 1991, Hoy and Tarter advanced Organizational Health Inventory (OHI) by making it specific for teachers basing on the above-mentioned theoretical approach.

Bryk and Driscoll [23] proposed three essential elements that constitute organizational settings of a school aiming to examine the structural and interpersonal characteristics of the school as an organization, consisting of 1) a common agenda of activities and schedules that were shared by students and teachers that connect them to each other as well as to the customs and norms of the school; 2) formal organizational characteristics, organizational characteristics among adults in regard to their formal responsibilities and collegiate interactions; and 3) shared value system, as in norms, values, and beliefs among people that construct the culture of the school system as a community.
Gottfredson [15] proposed the Effective School Battery (ESB) for the subordinate school environment assessment. The earliest ESB on student outcome related elements was covering 12 bodies: 1) Positive Peer Formations, 2) Education of Parents, 3) Anticipated Educational Outcomes, 4) Communal Competency, 5) Societal Unification, 6) SA, 7) Avoiding Punishment, 8) Obtaining Reward, 9) Integration, 10) SelfKnowledge, 11) School Performance, and 12) Reliance on Regulations. The ESB on teacher outcome elements involved seven bodies: 1) Occupational Fulfilment, 2) Interaction with Pupils, 3) Class Management, 4) Professional Competency, 5) Security, 6) Friendly Attitude, and 7) Perspective of Integration.

S. Brand, Felner, Shim, Seitsinger, and Dumas [24] presented the Inventory of School Climate-Student (ISC-S) with an emphasis on Students 'perception of School (SPS) and its environment. ISC-S was proposed after a couple of factors and the item analysis, and it consisted of 11 sub-measures, including 1) Supporting Teacher, 2) Consistent and Clear Expectations and Regulations, 3) Pupil Achievement Commitment Guidance, 4) Positive Peer Relations, 5) Negative Peer Relations, 6) Rigidity of Disciplines, 7) Decision-Making Process and 8) Student Involvement as well as 9) Educational Compatibility Innovation, 10) Assistance of Cultural Diversity, and 11) Issues of Safety.

\section{METHODOLOGY}

The research sample was obtained from 42 research and review papers written in the English language only, using A-Z Publications Finder (EBSCO) and Eric for education research content reaching from AUM Library; at the beginning, the papers were randomly selected using inclusion criteria of decade period time from 1908 to 2015 .

The methodology used in the present study was of a qualitative research type to describe, decode, and to discover meaning or to translate phenomenon in theories [25]. Based on the presented literature review, content analysis was used to present different theoretical foundations of adolescence based on Taqiuri's four scaled taxonomy on school attachment. Content analysis helped us to analyze the presence, meaning, and relationship of certain themes or concepts [26]. The main goal in the content analysis [27] was to choose a concept that was based on Tagiuri's four scaled taxonomy: ecology, milieu, social system, and culture, which were the codes of four thematic concepts. The Code of existence of a concept [28] was used in the analysis of the literature where a particular concept appeared al least once in a text. Based on coding, different theoretical foundations of school attachment were analyzed and presented in the "results" part in Table $\mathbf{1 .}$

Authors and an associate implemented categorization of 164 research and review papers based on content analysis that were conducted on the SA and Tagiuri's taxonomy, categorization was done independently first, and then inconsistencies were diagnosed thoroughly using the codes of four thematic concepts by authors to achieve a final categorization of research papers conducted only on Tagiuri's taxonomy in relation with organizational climate.

Moreover, an in-depth analysis of Tagiuri's taxonomy and 
attachment theory was used in relation to comprehension of social networks of schools that were obtained through secondary data as well as the table that was created for this study.

Table 1. Theoretical foundations of school attachment based on tagiuri's four scaled taxonomy on school attachment as an organization.

\begin{tabular}{|c|c|c|c|c|}
\hline - & Ecology & Milieu & Social System & Culture \\
\hline $\begin{array}{c}\text { Perry, A. } \\
\text { [60] }\end{array}$ & $\begin{array}{c}\text { significance of } \\
\text { school environment } \\
\text { in academic } \\
\text { achievement }\end{array}$ & $\begin{array}{l}\text { school environment should be } \\
\text { considered as part of the school, } \\
\text { calling it; "esprit de corps" }\end{array}$ & $\begin{array}{c}\text { Involvement of director, } \\
\text { teacher, and students as well } \\
\text { as the laypeople (alumni, } \\
\text { parents, etc.) }\end{array}$ & $\begin{array}{l}\text { school's primary duties to provide } \\
\text { an atmosphere that is more than a } \\
\text { simple "housing" }\end{array}$ \\
\hline McDill et al [17] & - & - & $\begin{array}{l}\text { Students` conception of } \\
\text { intellect \& esthetics }\end{array}$ & $\begin{array}{c}\text { - Academic ambition } \\
\text { - Science } \\
\text { - Human factor in perfectionism } \\
\text { - Success based student recognition }\end{array}$ \\
\hline $\begin{array}{l}\text { Moos } \\
{[18,19]}\end{array}$ & $\begin{array}{l}\text {-Ecology elements } \\
\text { - Environment of } \\
\text { behaviors } \\
\text { - Tangible ambiance }\end{array}$ & $\begin{array}{c}\text {-Traits of the people and } \\
\text { individuals living within the } \\
\text { organization } \\
\text { - Assembled people }\end{array}$ & Construction of the institution & $\begin{array}{c}\text { Endorsement features and } \\
\text { Utilitarian settings }\end{array}$ \\
\hline $\begin{array}{c}\text { Murphy et al. } \\
{[16]}\end{array}$ & - & - & $\begin{array}{l}\text { - Rules of accomplishment } \\
\text { - Activities of } \\
\text { accomplishment }\end{array}$ & $\begin{array}{c}\text { Anticipations on } \\
\text { accomplishment } \\
\text { - Standards for accomplishment } \\
\text { - Reinforcement for } \\
\text { accomplishment }\end{array}$ \\
\hline $\begin{array}{l}\text { Anderson } \\
{[30]}\end{array}$ & $\begin{array}{l}\text { Physical aspects } \\
\text { rather than people } \\
\text { within the school. }\end{array}$ & $\begin{array}{c}\text { The instruments, facilities, some } \\
\text { services, constructs, supplies, and } \\
\text { materials. }\end{array}$ & - & - \\
\hline McMillan et al. [61] & - & - & $\begin{array}{l}\text { Interpersonal relations, } \\
\text { standards, purposes, morals, } \\
\text { school activities, and } \\
\text { opportunities }\end{array}$ & $\begin{array}{c}\text {-School community focuses on the } \\
\text { human aspect of SA } \\
\text { - decision-making processes in } \\
\text { relation with a human aspect } \\
\end{array}$ \\
\hline Hoy et al. [22] & - & $\begin{array}{c}\text {-Organizational uprightness } \\
\text { - start point of infrastructure } \\
\text { - Deliberation } \\
\text { - Supplication of resources } \\
\text { - Self-esteem } \\
\end{array}$ & - & $\begin{array}{l}\text { The rephrase of academic } \\
\text { achievement and its perception by } \\
\text { teachers }\end{array}$ \\
\hline $\begin{array}{c}\text { Bryk \& Driscoll } \\
{[23]}\end{array}$ & - & $\begin{array}{c}\text { - Features of institutional } \\
\text { standards }\end{array}$ & $\begin{array}{l}\text { - Accepted calendar of } \\
\text { activities }\end{array}$ & $\begin{array}{l}\text { Norms \& values accepted and } \\
\text { shared by individuals }\end{array}$ \\
\hline Gottfredson $[15,62]$ & - & $\begin{array}{l}\text { - Communal basis } \\
\text {-Contentment } \\
\text { - Occupational training }\end{array}$ & $\begin{array}{l}\text {-Attitudes toward peers } \\
\text { - Reciprocal relations of } \\
\text { students and teachers } \\
\text { - Class settings }\end{array}$ & $\begin{array}{l}\text { Mental well-being and progress } \\
\text { - Measurements of school life } \\
\text {-integrative behaviors } \\
\text { - student-oriented freedom } \\
\text { - individual safety }\end{array}$ \\
\hline $\begin{array}{c}\text { Kuperminc, } \\
\text { Leadbetter, \& Blatt } \\
{[63]}\end{array}$ & - & $\begin{array}{l}\text { School milieu is defined through } \\
\text { intercommunication of variables } \\
\text { like; students, teachers, } \\
\text { administrators, schedule, tangible } \\
\text { surroundings, etc. }\end{array}$ & - & $\begin{array}{l}\text { Intercommunication of variables } \\
\text { together with the measurement of } \\
\text { quality and frequentness of } \\
\text { intercommunications and } \\
\text { interactions of the people at school } \\
\text { was described as school culture. }\end{array}$ \\
\hline $\begin{array}{l}\text { Brand et al., } \\
\quad[24]\end{array}$ & - & $\begin{array}{l}\text { - Openness to new instruction } \\
\text { methods }\end{array}$ & $\begin{array}{l}\text { - Supporting teachers } \\
\text { - Unfavorable student } \\
\text { interrelations } \\
\text { - Favorable student } \\
\text { interrelations } \\
\text { - Process of decision and } \\
\text { involvement of students }\end{array}$ & $\begin{array}{c}\text { - Clear and consistent rule policies } \\
\text { and anticipations } \\
\text { - Engagement, success, and training } \\
\text { of students } \\
\text { - Rigidity of rules } \\
\text { - Inclusiveness and support for } \\
\text { cultural diversity } \\
\text { - Security issues }\end{array}$ \\
\hline $\begin{array}{c}\text { Lee \& Bryk [38] } \\
\text { Konstantopoulos [37], } \\
\text { Benner et al. [48] }\end{array}$ & - & $\begin{array}{c}\text { Studies conducted on School } \\
\text { Milieu indicate a significant } \\
\text { correlation between SES and } \\
\text { academic achievement as students } \\
\text { from low SES scored low averages }\end{array}$ & - & - \\
\hline
\end{tabular}




\begin{tabular}{|c|c|c|c|c|}
\hline- & Ecology & Milieu & Social System & Culture \\
\hline $\begin{array}{l}\text { Wilson } \\
\text { [64] }\end{array}$ & $\begin{array}{l}\text { Individual } \\
\text { experiences through } \\
\text { school context were } \\
\text { regarded as school } \\
\text { bonding. }\end{array}$ & - & - & $\begin{array}{l}\text { student's level of connectedness } \\
\text { (high or low) was determined } \\
\text { through favorable or unfavorable } \\
\text { school climate. }\end{array}$ \\
\hline $\begin{array}{l}\text { Shendell } \\
\text { [32] }\end{array}$ & $\begin{array}{l}\text { higher correlation } \\
\text { between school } \\
\text { climate and health of } \\
\text { students }\end{array}$ & $\begin{array}{l}\text {-The noise in the classes was } \\
\text { found to be intervening with } \\
\text { learning. } \\
\text {-Enlightenment of the classes was } \\
\text { found to be increasing the } \\
\text { academic achievement. }\end{array}$ & - & - \\
\hline Mendel, Heath [31] & $\begin{array}{l}\text { school's ergonomics } \\
\text { and tangible } \\
\text { environment on } \\
\text { learning were } \\
\text { measured. }\end{array}$ & $\begin{array}{l}\text { presented findings on the effect of } \\
\text { moistened buildings which caused } \\
\text { more absences and low academic } \\
\text { achievements }\end{array}$ & - & - \\
\hline $\begin{array}{c}\text { Stone \& Han [52], } \\
\text { Fenzel \& O’Brennan } \\
\text { [51] } \\
\text { Brand et al. }[50]\end{array}$ & $\begin{array}{c}\text { safety at school had a } \\
\text { positive impact in } \\
\text { reducing disruptive } \\
\text { attitudes of the } \\
\text { students } \\
\end{array}$ & - & $\begin{array}{l}\text { well-ordered school systems } \\
\text { have a positive impact on } \\
\text { students` performances }\end{array}$ & -social well-being factors. \\
\hline $\begin{array}{c}\text { Loukas, Suzuki, \& } \\
\text { Horton } \\
{[65]} \\
\end{array}$ & - & $\begin{array}{c}\text { Students' attitude toward school } \\
\text { was measured through individuals. }\end{array}$ & - & - \\
\hline $\begin{array}{c}\text { Perera } \\
{[33]}\end{array}$ & - & - & $\begin{array}{c}\text {-Advancement of technology } \\
\text {-Data analysis, curriculum } \\
\text { development, assessment, } \\
\text { equipment, etc. }\end{array}$ & $\begin{array}{l}\text {-Computerized schools influenced } \\
\text { many aspects of schooling }\end{array}$ \\
\hline Hohlfeld et al. [34] & $\begin{array}{l}\text { K-12 schools were } \\
\text { investigated }\end{array}$ & - & $\begin{array}{l}\text { Based on the data they } \\
\text { presented on the differences } \\
\text { between accessibility and } \\
\text { support. }\end{array}$ & $\begin{array}{l}\text { Schools with better economy in } \\
\text { regard to SES were more prone to } \\
\text { technological development. }\end{array}$ \\
\hline $\begin{array}{l}\text { Leithwood \& Jantzi } \\
\qquad[35]\end{array}$ & $\begin{array}{l}\text { School size and its } \\
\text { impact on students }\end{array}$ & $\begin{array}{c}\text { Students with low SES } \\
\text { background indicated higher } \\
\text { performances in small-sized } \\
\text { schools }\end{array}$ & - & - \\
\hline $\begin{array}{c}\text { Jayaratne } \\
{[36]}\end{array}$ & - & - & $\begin{array}{c}\text { Ergonomics should be } \\
\text { considered under catering } \\
\text { services due to increasing } \\
\text { demand. }\end{array}$ & - \\
\hline Murphy et al. [56], & - & $\begin{array}{l}\text { Administrative staff should } \\
\text { achieve targeted goals. }\end{array}$ & - & $\begin{array}{c}\text { The academic performances of } \\
\text { students are also considered and } \\
\text { related with the institutional culture } \\
\text { of a school }\end{array}$ \\
\hline Leech \& Fulton [46] & - & - & - & $\begin{array}{l}\text {-positive impact of decision- } \\
\text { making } \\
\text { - participation of students on } \\
\text { teacher discourses }\end{array}$ \\
\hline $\begin{array}{c}\text { Bruce et al. }[41] \text {, } \\
\text { Wyatt } \\
{[45]} \\
\text { Luck [44] } \\
\text { Jannati, et al. }[42] \text {, } \\
\text { Lemberger et al. }[43] \text {, }\end{array}$ & - & $\begin{array}{l}\text {-Significance of counseling } \\
\text { activities in regard to school } \\
\text { psychology }\end{array}$ & $\begin{array}{c}\text {-Presented findings indicated } \\
\text { that counseling activities at a } \\
\text { school increased rates of } \\
\text { passing from high-stake } \\
\text { exams }\end{array}$ & - \\
\hline Feuer et al. [47] & - & - & $\begin{array}{l}\text {-They could not provide } \\
\text { precise data indicating its } \\
\text { concrete influence on the } \\
\text { school system. }\end{array}$ & $\begin{array}{c}\text { Emphasized the importance of } \\
\text { student's priority in decision- } \\
\text { making process. }\end{array}$ \\
\hline Fisher et al. [55] & - & $\begin{array}{l}\text { Importance on the strategic plan } \\
\text { that should be implemented at the } \\
\text { very beginning. }\end{array}$ & - & - \\
\hline $\begin{array}{l}\text { Fox } \\
{[58]}\end{array}$ & - & - & - & $\begin{array}{c}\text { Culture is one of the major devices } \\
\text { to initiate and maintain an } \\
\text { organization. }\end{array}$ \\
\hline
\end{tabular}




\begin{tabular}{|c|c|c|c|c|}
\hline- & Ecology & Milieu & Social System & Culture \\
\hline $\begin{array}{c}\text { Labianca et al., } \\
{[29]}\end{array}$ & $\begin{array}{l}\text { Structural approach } \\
\text { to organization }\end{array}$ & - & - & - \\
\hline Lavrijsen et al. [54] & - & - & $\begin{array}{l}\text { The design of the school } \\
\text { system and features of SES } \\
\text { context was also mentioned } \\
\text { to influence dropout and } \\
\text { truancy risks }\end{array}$ & - \\
\hline Daud et al. [59], & $\begin{array}{c}\text { several different } \\
\text { cultures practiced at } \\
\text { different schools can } \\
\text { be used to } \\
\text { conceptualize school } \\
\text { culture profiles }\end{array}$ & - & $\begin{array}{l}\text { enhance school practices by } \\
\text { all means, including } \\
\text { academic achievement, } \\
\text { instructional quality, } \\
\text { achieving targeted goals, etc. }\end{array}$ & $\begin{array}{l}\text { The study conducted types of } \\
\text { school cultures }\end{array}$ \\
\hline Tok [39] & - & $\begin{array}{l}\text { The influence of SES was } \\
\text { discussed in accordance with } \\
\text { performance }\end{array}$ & - & - \\
\hline
\end{tabular}

\section{RESULTS}

Tagiuri et al. [3] developed a four-scaled classification for School Environment: ecology, milieu, social system, and culture. Although Tagiuri's classification of School Climate intrigued a structural approach to organizations, it was later perceived as taxonomies that were based on aspects of valence: "Studies of social networks in the organizational arena have taken varying approaches over time..." as they "...focused on whether ties between nodes existed or not with a relational content approach" [29].

\subsection{Ecology}

Ecology, in regard to school, addresses physical aspects rather than people within the school, which covers the instruments, facilities, some services, constructs, supplies, and materials [30]. The impact of school's ergonomics and tangible environment on learning was measured by Mendell and Heath [31]. They presented findings on the effect of moistened buildings, which caused more absences and low academic achievements on students. In another study, Shendell, Barnett, and Boese [32] presented a higher correlation between school climate and health of students, particularly the noise in the classes was found to be intervening with learning; however, the enlightenment of the classes was found to be increasing the academic achievement.

The advancement of technology was also mentioned by Perera [33] as the increase in computerized schools influenced many aspects of schooling: data analysis, curriculum development, assessment, equipment, etc. K-12 schools were investigated by Hohlfeld, Ritzhaupt, Barron, and Kemker [34] proposing that schools with a better economy in regard to SES were more prone to technological development according to the results they presented on the differences between accessibility and support. Leithwood and Jantzi [35] presented a study on school size and its impact on students; they suggested that students with low SES background indicated higher performances in small-sized schools. Jayaratne [36] suggested that ergonomics should be considered under catering services due to the increasing demand.

\subsection{Milieu}

It is about the characteristics of the people within the school system [3], also considered with two aspects of human factor: (a) students' characteristics in regard to family, ethnicity, performance, etc. and (b) teachers' characteristics with their experiences, academic and credential backgrounds. Studies conducted on School Milieu indicate a significant correlation between SES and academic achievement as students from low SES scored low averages [37, 38]. The influence of SES was analyzed in accordance with performance: School performance, Academic achievement, in other words, was effected by the socio-economic status as those who belonged to high socioeconomic status showed higher performances [39]. Many other studies highlighted the significance of counseling activities in regard to school psychology that studied academic matters as well, through which the presented findings indicated that counseling activities at a school significantly increased the ratio of passing from high-stake tests [40 - 45].

\subsection{Social System}

Social System refers to established and non-established operational designs and the interrelations among populations and their divisions within the organization of a school [3]. The positive impacts of decision-making through encouraging participation of students in teacher discourses and values are mentioned by Leech and Fulton [46] in regard to schools social system. Although Feuer and Mayer [47] emphasized the importance of student's priority in the decision-making process of the school, they could not provide any precise data indicating its concrete influence.

As mentioned earlier on the milieu of school that counseling activities have a positive impact on students' achievements, in the same study conducted by Benner, Allor, and Mooney [48], the authors suggested that the social system of a school is positively influenced by the interaction of pupil learning results and social elements. The supportive approach in regard to academic achievement from teachers, counselors, and admin staff has many advantages for pupils' success [48, 49]. According to several other studies, social well-being factors and well-ordered school systems have a positive impact on students ' performances; likewise, safety at school had a positive impact on reducing disruptive attitudes of the students [50 - 52]. Other recent studies mentioned the significance of 
social competence and its impact on academic achievement: the findings presented indicated that competence in social skills and the systems of schools (as in private $v s$. public) were given as important predictors of school (academic) achievement. In this regard, there were significant differences between the achievements of high scoring and low scoring students' in their overall competencies [53]. The design of a school system and features of SES context was also mentioned to influence dropout and truancy risks [54].

\subsection{Culture}

According to Tagiuri et al. [3], the culture of a school system features the same characteristics with a community or society as people and their interrelations with each other determine the same beliefs, norms, and values. Studies conducted on school culture emphasize the importance of the strategic plan that should be implemented at the very beginning in regard to ecology, milieu and social system: "Organizations, including schools, should make building culture part of a planned strategic effort" [54]. The academic performances of students are also considered and related to the institutional culture of a school as it helps the administrative staff to achieve targeted goals $[56,57]$.

Identification of the kind of culture within a school is also considered significant and studies indicate that culture is one of the major indicators to initiate and maintain an organization [58]. Variables based on several different cultures practiced at different schools can be used to conceptualize school culture profiles; moreover, they can be used to enhance school practices by all means, including academic achievement, instructional quality, achieving targeted goals, etc. as Daud, Raman, Don, Sofian, and Hussin [59] reached results on a study conducted on the types of school cultures: "An organizational culture which is both strong and appropriate with the aspirations of the members in the organization can help preserve excellence in the organization and help in achieving aims and objectives" [58].

Together with technological developments and other prerequisites, high performances expected from students, as well as the need for communal success and integrity, are increased proportionally. Adolescents that are lacking in one or more of these aspects have less chance of furthering their studies and $\backslash$ or maintaining their socio-psychological well beings. Accordingly, the analysis of organizational climate overall suggests that attachment with all its aspects is one of the vital requirements in providing support for adolescent development. SA in particular with its physical aspects about the environment, staff, culture, ecology, etc.; academic aspects of learning, interest, achievement, performance, instruction, etc.; and psychological aspects of development, general wellbeing, integrity, satisfaction, etc. are all essential components that have an impact on students, teachers, administrative staff, school, and governmental outcomes.

\section{DISCUSSION}

Studies conducted on school climate, overall indicate that styles of attachment have an impact on personality traits and the professional life of an individual. Thus, environmental factors are also as important as an individual`s attachment patterns, because both have an influence on development as in: "Developmental Theorists are now looking at much more diverse populations and attachment theorists need to follow their lead" $[65,66]$.

Together with the rising interest of the researchers and the conceptualized significance of attachment studies implemented on adolescents, psychologists, practitioners, counselors, pedagogues, curriculum designers, governmental, and nongovernmental policy-making agents are getting more and more devoted to the full comprehension of attachment variables and establishment of the safe havens that can cultivate adolescents' attachments to their schools $[1,2,14,67,68]$. On the other hand, the current paper, together with the literature on the theme as well as Table 1, indicates that although research on SA related performance enhancement with organizational settings, the scales assessing climate enhancement are significantly neglected. As the data on Table 1 shows only 3 studies (7.14\%) of the research from 1908 to 2015 focused on all four scales of the taxonomy; 9 studies $(21.4 \%)$ of the research used three of them; 19 studies $(45.2 \%)$ used two of the scales and 11 studies $(26.1 \%)$ of the research used only one of the scales. However, one of the other aspects of schools which should be considered by school psychologists is that they are organizational places where students can socialize with others. According to Barber \& Muenz [69], adolescents socialize with others through different aspects, such as having close relations with others, displaying regulated behaviors, and initiating autonomy for psychological development. The approach of seeing schools as social settings indicates that schools provide the first aspect by helping students socialize, especially when they are well-organized to be cultures or environments of caring $[40,70]$.

\section{CONCLUSION}

Although there have been different viewpoints on the approach of schools' functions as social environments, the scholars majorly agreed on the facts that schools help students, experience emotional bonding to each other as they develop attachment feelings [1], they experience senses like being respected, helped and cared by peers and teachers, in such schools students are felt like being at home [1]. One of the benefits provided by such caring schools is that students experience senses such as being part of a bigger group where they have their roles and contributions; such school climates give students a chance to have a word in decision-making processes in the school activities as well. The impact of such schools on the student development is widely appreciated by scholars as such schools bring up systems with value, higher satisfaction, enhanced school performance, lower delinquency behavior, and overall healthy school attachment $[40,70]$. The role of school attachment in preventing delinquency and fostering healthy development is one of the majorly and pervasively agreed influences of SA on students.

\section{ETHICS APPROVAL AND CONSENT TO PARTI- CIPATE}

Not applicable. 


\section{HUMAN AND ANIMAL RIGHTS}

No human/animals were used that are basis of this study.

\section{CONSENT FOR PUBLICATION}

Not applicable.

\section{AVAILABILITY OF DATA AND MATERIALS}

Not applicable.

\section{FUNDING}

None.

\section{CONFLICT OF INTEREST}

The author declares no conflict of interest, financial or otherwise.

\section{ACKNOWLEDGEMENTS}

Declared none.

\section{REFERENCES}

[1] Libbey HP. Measuring student relationships to school: attachment, bonding, connectedness, and engagement. J Sch Health 2004; 74(7): 274-83.

[http://dx.doi.org/10.1111/j.1746-1561.2004.tb08284.x] [PMID: 15493704]

[2] Catalano RF, Haggerty KP, Oesterle S, Fleming CB, Hawkins JD. The importance of bonding to school for healthy development: Findings from the social development research group. J Sch Health 2004; 74(7): 252-61.

[http://dx.doi.org/10.1111/j.1746-1561.2004.tb08281.x] [PMID: 15493702]

[3] Tagiuri R, Litwin GH, Barnes LB. Organizational climate: explorations of a concept. Boston: Division of Research, Graduate School of Business Administration, Harvard University 1968.

[4] Ainsworth MD. Infant--mother attachment. Am Psychol 1979; 34(10): 932-7.

[http://dx.doi.org/10.1037/0003-066X.34.10.932] [PMID: 517843]

[5] Bowlby J. Attachment and Loss: Attachment. Basic Books 1969

[6] Hirschi T. Causes of Delinquency. Transaction Publishers 2002.

[7] Hawkins JD, Weis JG. The social development model: An integrated approach to delinquency prevention. J Prim Prev 1985; 6(2): 73-97. [http://dx.doi.org/10.1007/BF01325432] [PMID: 24271382]

[8] O'Farrell SL, Morrison GM. A factor analysis exploring school bonding and related constructs among upper elementary students. Contemp Sch Psychol 2003; 8(1): 53-72.

[9] Blum R. School connectedness: Improving the lives of students. Baltimore: Johns Hopkins Bloomberg School of Public Health 2005.

[10] Schulz LL, Rubel DJ. A Phenomenology of Alienation in High School: The Experiences of Five Male Non-completers. Professional School Counseling 2011; 1;14(5) 2156759X1101400501

[11] Aslan M, Rosinaite V, Khojanashvili L. Social control theory variables in conceptualizing bonding models of attachment theory and adolescent development. Acad J Interdisciplinary Stud 2019; 8(2): 199.

[http://dx.doi.org/10.2478/ajis-2019-0031]

[12] Benson PL. Adolescent development in social and community context: a program of research. New Dir Youth Dev 2002; 2002(95): 123-47. [http://dx.doi.org/10.1002/yd.19] [PMID: 12448289]

[13] Scales PC. Developmental Assets and the Middle School Counselor 2005; 1;9(2) 2156759X0500900205

[14] Bryan J, Day-Vines N, Griffin D, Moore-Thomas C. The disproportionality dilemma: Patterns of teacher referrals to school counselors for disruptive behavior. J Couns Dev 2012; 90(2): 177-90. [http://dx.doi.org/10.1111/j.1556-6676.2012.00023.x]

[15] Gottfredson GD. Using the Effective School Battery in School Improvement and Effective Schools Programs [Internet] 1986. Available from: https://eric.ed.gov/?id=ED273041

[16] Murphy JF, Weil M, Hallinger P, Mitman A. Academic press:
Translating high expectations into school policies and classroom practices. Educ Leadersh 1982; 40(3): 22-6.

[17] McDill EL, Rigsby LC, Meyers Edmund D. Educational climates of high schools: Their effects and sources. Am J Sociol 1969; 74(6): 567-86.

[http://dx.doi.org/10.1086/224711]

[18] Moos RH. Conceptualizations of human environments. Am Psychol 1973; 28(8): 652-65.

[http://dx.doi.org/10.1037/h0035722]

[19] Moos RH, Clayton J, Max W. The social climate scales: An annotated bibliography. Consulting Psychologists Press 1979.

[20] Moos RH, Moos BS. Family environment scale manual. Palo Alto, Calif.: Consulting Psychologists Press 1994.

[21] Hoy WK, Fedman JA. Organizational Health: The Concept and Its Measure. J Res Dev Educ 1987; 20(4): 30-7.

[22] Hoy WK, Tarter CJ. Measuring the Health of The School Climate: A Conceptual Framework. NASSP Bull 1992; 76(547): 74-9.

[http://dx.doi.org/10.1177/019263659207654709]

[23] Bryk AS, Driscoll ME. The high school as community: contextual influences and consequences for students and teachers 1988. Available from: https://eric.ed.gov/?id=ED302539

[24] Brand S, Felner R, Shim M, Seitsinger A, Dumas T. Middle school improvement and reform: Development and validation of a schoollevel assessment of climate, cultural pluralism, and school safety. J Educ Psychol 2003; 95(3): 570-88.

[http://dx.doi.org/10.1037/0022-0663.95.3.570]

[25] Easterby-Smith M, Thorpe R, Lowe A. Management Research: An Introduction Koper: Fakulteta za management 2005.

[26] Charmaz K. Constructing Grounded Theory: A Practical Guide Through Qualitative Analysis. London, UK: SAGE Publications Ltd. 2006.

[27] Krippendorf K. Content analysis: An introduction to its methodology. Beverly Hills, California: Sage Publications 1980.

[28] Elo S, Kääriäinen M, Kanste O, Pölkki T, Utriainen K, Kyngäs H. Qualitative Content Analysis: A Focus on Trustworthiness. SAGE Open 2014; 4(1)2158244014522633

[http://dx.doi.org/10.1177/2158244014522633]

[29] Labianca G (Joe). Negative Ties in Organizational Networks. In: Contemporary Perspectives on Organizational Social Networks [Internet]. In: Emerald Group Publishing Limited. 2014; 40: pp. 239-59.

[http://dx.doi.org/10.1108/S0733-558X(2014)0000040012]

[30] Anderson CS. The search for school climate: A review of the research: review of educational research [Internet] 2016.https://journals.sagepub.com

[http://dx.doi.org/10.3102/00346543052003368]

[31] Mendell M, Heath G. A summary of scientific findings on adverse effects of indoor environments on students' health, academic performance and attendance. LBNL for the US Department of Education 2004.

[32] Shendell DG, Barnett C, Boese S. Science-based recommendations to prevent or reduce potential exposure to biological, chemical, and physical agents in schools. J Sch Health 2004; 74(10): 390-6. [http://dx.doi.org/10.1111/j.1746-1561.2004.tb06603.x] [PMID: 15724565]

[33] Perera PG. How computer -related technology is incorporated into instructional methods and objectives in the secondary school classroom [Internet] 2008. Available from: https://search.proquest.com/openview/d8deef003fd1b5900be506b403d 1be04/1?pq-origsite $=$ gscholar\&cbl $=18750 \&$ diss $=y$

[34] Hohlfeld TN, Ritzhaupt AD, Barron AE, Kemker K. Examining the digital divide in K-12 public schools: Four-year trends for supporting ICT literacy in Florida. Comput Educ 2008; 51(4): 1648-63.

[http://dx.doi.org/10.1016/j.compedu.2008.04.002]

[35] Leithwood K, Jantzi D. A Review of Empirical Evidence About School Size Effects: A Policy Perspective: Review of Educational Research [Internet] 2009. Available from: https://journals.sagepub.com10.3102/0034654308326158

[36] Jayaratne K. Ergonomic considerations in school environments - the need for widening the scope. Work 2012; 41(Suppl. 1): 5543-6. [http://dx.doi.org/10.3233/WOR-2012-0877-5543] [PMID: 22317609]

[37] Konstantopoulos S, Borman G. Family Background and School Effects on Student Achievement: A Multilevel Analysis of the Coleman Data. Teach Coll Rec 2011; 113(1): 97-132.

[38] Lee VE, Bryk AS. A multilevel model of the social distribution of high school achievement. Sociol Educ 1989; 62(3): 172-92. [http://dx.doi.org/10.2307/2112866] 
[39] Tok BR, Dupak S. A study on academic achievement in relation with socio economic status of secondary school students with reference to east siang district of arunachal pradesh. Int J Multidisciplinary App \& Stud 2015; 2(5)

[40] Aslan M. Analysis of school attachment among students of a boarding high school in albania. J Educ Soc Res 2014; 4(2): 287. [http://dx.doi.org/10.5901/jesr.2014.v4n2p287]

[41] Bruce AM, Getch YQ, Ziomek-Daigle J. Closing the Gap: A Group Counseling Approach to Improve Test Performance of AfricanAmerican Students. Professional School Counseling 2009; 1;12(6) 2156759X0901200603

[42] Jannati Y, Khaki N, Sangtarashani EOSS, Peyrovi H, Amiri Nojadeh $\mathrm{N}$. The effect of supportive counseling program on the academic performance of nursing and midwifery students. Contemp Nurse 2012; 43(1): 113-20

[http://dx.doi.org/10.5172/conu.2012.43.1.113] [PMID: 23343240]

[43] Lemberger ME, Selig JP, Bowers H, Rogers JE. Effects of the student success skills program on executive functioning skills, feelings of connectedness, and academic achievement in a predominantly hispanic, low-income middle school district. J Couns Dev 2015; 93(1): 25-37.

[http://dx.doi.org/10.1002/j.1556-6676.2015.00178.x]

[44] Luck L, Webb L. School Counselor Action Research: A Case Example. Professional School Counseling 2009; 1;12(6) 2156759X0901200609

[45] Wyatt S. The brotherhood: Empowering adolescent African-American males toward excellence. Prof Sch Couns 2009; 12(6): 463-70. [http://dx.doi.org/10.5330/PSC.n.2010-12.463]

[46] Leech D, Fulton CR. Faculty perceptions of shared decision making and the principal's leadership behaviors in secondary schools in a large urban district. Education 2008; 128(4): 630-44.

[47] Feuer A, Mayer A. Student Board Members Make a Difference. Educ Dig 2009; 74(9): 17-9.

[48] Benner GJ, Allor JH, Mooney P. An investigation of the academic processing speed of students with emotional and behavioral disorders served in public school settings. Educ Treat Child 2008; 31(3): 307-32. [http://dx.doi.org/10.1353/etc.0.0006]

[49] Košir S. Study support as students' motivation for study. Int J Manag Educ 2010; 4(1) [IJMIE].

[50] Brand PLP, Baraldi E, Bisgaard H, et al. Definition, assessment and treatment of wheezing disorders in preschool children: an evidencebased approach. Eur Respir J 2008; 32(4): 1096-110. [http://dx.doi.org/10.1183/09031936.00002108] [PMID: 18827155]

[51] Fenzel LM, O'Brennan LM. Educating at-risk urban african american children: The effects of school climate on motivation and academic achievement [internet] online submission 2007. Available from: https://eric.ed.gov/?id=ED497443

[52] Stone S, Han M. Perceived school environments, perceived discrimination, and school performance among children of Mexican immigrants. Child Youth Serv Rev 2005; 27(1): 51-66. [http://dx.doi.org/10.1016/j.childyouth.2004.08.011]

[53] Malik F, Shujja S. Social competence and school systems as predictor of academic achievement in high and low achieving pakistani school children. J Behav Sci 2013; 23(1): 77-92.

[54] Lavrijsen J, Nicaise I. Social inequalities in early school leaving: The role of educational institutions and the socioeconomic context. Eur Educ 2015; 47(4): 295-310.

[http://dx.doi.org/10.1080/10564934.2015.1098265]

[55] Fisher D, Frey N, Pumpian I. How to Create a Culture of Achievement in Your School and Classroom. ASCD 2012.

56] Murphy J, Smylie M, Mayrowetz D, Louis KS. The role of the principal in fostering the development of distributed leadership. Sch Leadersh Manage 2009; 29(2): 181-214.

[http://dx.doi.org/10.1080/13632430902775699]

[57] Robbins SP. Organizational Behavior [Internet]. USA: San Diego State University 2011. content/one-dot-com/one-dot-com/us/en/highereducation/product.html

[58] Fox JR. Analyzing the organizational culture of Yolo county using two assessment models [Internet]. [Sacramento]: California State University 2013. Available from: paper/Analyzing-the-organizationalculture-of-Yolo-county-

Fox/f635af1cfd2ce39288dafd1755bcc1894fd65c7b

[59] Daud Y, Raman A, Don Y. O. F. MS, Hussin F. The type of culture at a high performance schools and low performance school in the state of kedah. Int Educ Stud 2015; 8(2): 21-31.

[http://dx.doi.org/10.5539/ies.v8n2p21]

[60] Perry AC. The management of a city school. Macmillan 1914

[61] McMillan DW, Chavis DM. Sense of community: A definition and theory. J Community Psychol 1986; 14(1): 6-23.

[http://dx.doi.org/10.1002/1520-6629(198601)14:1<6::AID-JCOP2290 $140103>3.0 . \mathrm{CO} ; 2-\mathrm{I}]$

62] Gottfredson GD, Gottfredson DC, Payne AA, Gottfredson NC. School climate predictors of school disorder: results from a national study of delinquency prevention in schools. J Res Crime Delinq 2005; 42(4): 412-44.

[http://dx.doi.org/10.1177/0022427804271931]

[63] Kuperminc GP, Leadbeater BJ, Blatt SJ. School social climate and individual differences in vulnerability to psychopathology among middle school students. J Sch Psychol 2001; 39(2): 141-59. [http://dx.doi.org/10.1016/S0022-4405(01)00059-0]

64] Wilson D. The interface of school climate and school connectednes and relationships with aggression and victimization. J Sch Health 2004; 74(7): 293-9.

[http://dx.doi.org/10.1111/j.1746-1561.2004.tb08286.x]

[PMID: 15493706]

[65] Loukas A, Suzuki R, Horton KD. Examining school connectedness as a mediator of school climate effects. J Res Adolesc 2006; 16(3): 491-502.

[http://dx.doi.org/10.1111/j.1532-7795.2006.00504.x]

[66] Austrian SG, Ed. Developmental Theories Through the Life Cycle 2nd ed. Columbia University Press 2008.

[67] Eccles JS, Roeser RW. Schools, academic motivation, and stageenvironment fit.Individual bases of adolescent development. 3rd ed. Handbook of adolescent psychologyHoboken, NJ, US: John Wiley \& Sons Inc 2009; 1: pp. 404-34.

[68] Smith DC, Sandhu DS. Toward a positive perspective on violence prevention in schools: Building connections. J Couns Dev 2004; 82(3): 287-93.

[http://dx.doi.org/10.1002/j.1556-6678.2004.tb00312.x]

[69] Barber JP, Muenz LR. The role of avoidance and obsessiveness in matching patients to cognitive and interpersonal psychotherapy: empirical findings from the treatment for depression collaborative research program. J Consult Clin Psychol 1996; 64(5): 951-8. [http://dx.doi.org/10.1037/0022-006X.64.5.951] [PMID: 8916624]

[70] Battistich V, Hom A. The relationship between students' sense of their school as a community and their involvement in problem behaviors. Am J Public Health 1997; 87(12): 1997-2001. [http://dx.doi.org/10.2105/AJPH.87.12.1997] [PMID: 9431290]

\section{(C) 2020 Aslan et al.}

This is an open access article distributed under the terms of the Creative Commons Attribution 4.0 International Public License (CC-BY 4.0), a copy of which is available at: https://creativecommons.org/licenses/by/4.0/legalcode. This license permits unrestricted use, distribution, and reproduction in any medium, provided the original author and source are credited. 